\title{
Analisis Potensi Ekonomi Pada Setiap Kecamatan Dalam Pengembangan Pembangunan Ekonomi di Kabupaten Lombok Utara
}

\author{
Putu Karismawan*, Muhammad Alwi, Bq Ismiwati \\ Fakultas Ekonomi dan Bisnis, Universitas Mataram
}

*Corresponding Email: putukarismawan@unram.ac.id

\begin{tabular}{ll}
\hline \multicolumn{1}{c}{ Info Artikel } & ABSTRAK \\
\hline Kata Kunci: & Penelitian ini dilaksanakan di Desa Wisata Sesaot \\
Potensi Ekonomi & Kecamatan Narmada Kabupaten Lombok Barat. Tujuan \\
dilakukan penelitian ini adalah untuk mengetahui bagaimana & Strategi Penerapan Konsep Sustainable Tourism di Desa Wisata \\
& Sesaot Kec Narmada Kab Lombok Barat. \\
& Pendekatan yang digunakan dalam penelitian ini adalah \\
pendekatan kualitatif dengan metode deskriptif. Metode analisis \\
data yang digunakan untuk menganalisis data pada penelitian ini \\
alat analisis SWOT (Strong, Weakness, Opportunity, dan \\
Threat). \\
Hasil penelitian ini menemukan Faktor Pendorong \\
Penerapan Konsep Sustainable Tourism di Desa Wisata Sesaot. \\
yang memperoleh kategori sangat tinggi adalah penataan desa \\
wisata yang sangat indah dan asri, keindahan budaya (penduduk \\
muslim dan hindu hidup berdampingan), sumber air melimpah, \\
memiliki keunggulan produk perkebunan (buah-buahan), lokasi \\
yang tidak terlalu jauh dari pusat kota. Faktor penghambat \\
Penerapan Konsep Sustainable Tourism di kawasan wisata \\
memperoleh rata-rata dengan kategori tinggi adalah rendahnya \\
SDM masyarakat dalam pengembangan desa wisata, promosi \\
dan pemasaran wisata kurang optimal, fasilitas di lokasi yang \\
kurang memadai, kurangnya tenaga ahli dalam pengelolaan \\
kawasan wisata dan kurangnya partisifasi pemerintah dalam \\
pengembangan potensi desa.
\end{tabular}
pengembangan potensi desa.

Key words : economic potentiality.
Identifiction of ecocomic potentiallity of sub districts of

District North Lombok most important as base of acurate development planning, so the growth of development of District North Lombok can be faster. Base on this so the objectives of this research is to know economic potentiality of each sub district by sectoral in District North Lombok base on three criteria: fisrstly is economic sectors that fulfill as sectotral base ecocomic; secondly is sectors that have economic advantages or competitivness, and thirdly is sectors that have criteria as developed and fastest growth sectors relatively in District North Lombok. 


\section{Elastisitas - Jurnal Ekonomi Pembangunan \\ Vol. 2 No. 2, September 2020}

To reach of these objective of this research Gross Domestic Regional Product all of the ecocnomic sectors each sub district of District North Lombok will be anlyze by Location Quotient (LQ), Shift-Share and Klassen Typology simultaneously. The criteria of the Economic potensial Sectors are the sectors have $L Q>1$, developed and have faster growth with comparative or competitive advantages.

The result are as follow: The potencial sectors of Gangga Sub District are Agricultural sector, suport by livestock sub sectors and forestry. Next, Minning, Trade, sevices sectors. The potencial sector of Pemenang Sub District are plantation, Fishery, water supply, construction, , Hotel and Restaurant, Taransport and communication, Financial and services sectors. The potencial sectors of Tanjung Sub Dsitrict are Plantation, and Fishery,water supply, Construction, Hotel and Restauitrant, Transportation and Communication, Financial and ownership Business services. The potencial sectors of Bayan Sub District are Agricultural, Plantation, Livestock and Fishery, Construction sectors. The potencial sectors of Kayangan sub district are Agricultral: such as Livesstock, next Tarde, Hotel and Restaurant sectors.

Recommendation of this result to development policy maker of sub and district North Lombok are that in development planning have to consider the potential sector and in develpment of industry have to corespond with economic potentiality of each sub district.

\section{PENDAHULUAN}

Propinsi Nusa Tenggara Barat terdiri atas 8 kabupaten dan 2 kota yang terdiri dari kabupaten: Lombok Barat, Lombok Timur. Lombok Tengah, Lombok Utara, Bima, Dompu, Sumbawa Besar, Sumbawa Barat dan 2kota yaitu Kota Mataram dan kota Bima. Pada setiap Kabupaten dan kota yang ada di provinsi NTB tersebar potensi Sumberdaya baik sumberdaya alam maupun sumberdaya manusia demikian pula tersebar pada setiap kecamatan yang ada termasuk kecamatan yang ada di Kabupaten Lombok Utara. Kabupaten ini baru terpisah dari Kabupaten Lombok Barat sejak tahun 2008.Oleh karena itu, maka perlu suatu strategi pembangunan yang tepat agar dapat mengejar ketertinggalannya dari kabupaten yang duluan terbentuk. Kabupaten Lombok Utara pada umumnya berupa pegunungan dan masyarakatnya umumnya bermukim di wilayah pantai dengan penghasilan utamanya dari sektor pertanian dalam arti luas. Potensi sumberdaya yang dimiliki oleh daerah ini akan berpengaruh terhadap pertumbuhan PDRB Kabupaten ini. Di mana kabupaten Lombok utara terdiri atas lima kecamatan sebagai berikut :
a. Kecamatan Pemenang
b. Kecamatan Tanjung
c. Kecamatan Gangga
d. Kecamatan Kayangan
e. Kecamatan Bayan

Tentu kelima Kecamatan di atas memiliki potensi ekonomi masing-masing karena sangat tergantung pada sumberdaya yang dimiliki setiap kecamatan yang di Kabupaten Lombok Utara. Berdasarkan hal tersebut maka perlu diketahui potensi ekonomi yang dimiliki masing-masing Kecamatan akan dapat berpengaruh terhadap pengembangan pembangunan ekonomi. Kemudian karena potensi wilayah kecamatan yang ada berbedabeda, maka perlu melakukan identifikasi sektor potensi ekonomi daerah hingga 


\section{Elastisitas - Jurnal Ekonomi Pembangunan \\ Vol. 2 No. 2, September 2020}

rencana strategis program-program ada terarah dengan tepat sehingga tercipta pengembangan pembangunan ekonomi. Ada dua faktor utama yang perlu diperhatikan dalam mengidentifikasi potensi ekonomi daerah yaitu sektor ekonomi yang unggul atau mempunyai daya saing yang kuat dan sektor ekonomi yang potensial untuk dikembangkan. Kedua faktor ini dapat menjadi dasar dalam program-program prioritas sektor ekonomi dalam pengembangan pembangunan ekonomi.

\section{Perumusan Masalah}

Berdasarkan uraian di atas, maka dapat dirumuskan masalah sebagai berikut:

a. Sektor-sektor ekonomi manakah yang termasuk sektor basis pada setiap kecamatan yang ada di Kabupaten Lombok Utara.

b. Sektor-sektor ekonomi manakah yang memiliki keunggulan kompetetif atau daya saing pada setiap kecamatan di kabupaten Lombok Utara.

c. Sektor-sektor ekonomi yang mana yang merupakan sektor maju dan cepat tumbuh pada setiap kecamatan di Kabupaten Lombok Utara

d. Sektor-sektor ekonomi yang mana yang memiliki ketiga kriteria di atas (Sektor basis, memiliki keunggulan kompetitif serta maju dan tumbuh cepat) yang merupakan sektor ekonomi potensial pada setiap Kecamatan di Kabupaten Lombok Utara.

\section{Tujuan Penelitian}

a. Untuk mengetahui sektor ekonomi yang merupakan sektor basis pada setiap kecamatan di Kabupaten Lombok Utara.

b. Untuk mengetahui sektor ekonomi yang memiliki keunggulan kompetitif atau daya saing pada setiap kecamatan di Kabupaten Lombok Utara.

c. Untuk mengetahui sektor ekonomi yang maju dan tumbuh cepat pada setiap kecamatan di Kabupaten Lombok Utara. d. Untuk mengetahui potensi ekonomi pada setiap kecamatan yang ada di Kabupaten Lombok Utara.

\section{Kegunaan Penelitian}

a. Dapat digunakan oleh pemerintah sebagai bahan dalam membuat strategi perencanaan pembanguna pada setiap kecamatan di Kabupaten Lombok Utara.

b. Dapat digunakan oleh swasta sebagai acuan dalam milih sektor ekonomi untuk investasi di Kabupaten Lombok Utara.

\section{METODE PENELITIAN Jenis Penelitian}

Jenis penelitian yang digunakan adalah penelitian deskriptif, yaitu suatu metode dalam meneliti status kelompok manusia, suatu objek, suatu kondisi, suatu sistem pemikiran ataupun suatu peristiwa pada masa sekarang guna membuat diskripsi, gambaran atau lukisan secara sistimatis, faktual dan akurat mengenai fakta-fakta serta hubungan antara yang diselidiki, dianalisis kemudian disimpulkan. (Nazir, 1999:63).

\section{Lokasi Penelitian}

Penelitian ini akan dilakukan pada setiap Kecamatan di Kabupaten Lombok Utara Nusa tenggara Barat, pemilihan lokasi ini didasarkan pada pertimbangan bahwa Kabupaten Lombok Utara merupakan Kabupten yang termudah dari pemekaran KabupatenLombok Barat. Sedangkan sumberdaya ekonomi yang ada cukup berpotensiuntuk dapat meningkatkan pendapatan daerah Kabupaten Lombok Utara, Oleh karena itu perlu diketahuipotensi ekonomi yang dimiliki setiap kecamatan di Kabupaten Lombok Utara dalam pengembangan pembangunan ekonomi wilayah sehingga tidak tertinggal dengan Kabupaten dan Kota yang ada di Propinsi Nusa Tenggara Barat. 


\section{Elastisitas - Jurnal Ekonomi Pembangunan \\ Vol. 2 No. 2, September 2020}

\section{Metode Pengumpulan Data}

Mengumpulan data dilakukan dalam penelitian ini adalah metode kasus (case study) yaitu penelitian tentang suatu status subjek yang berkenaan dengan suatu pase spesifik atau khas dari keseluruhan personalitas di mana subjek ini bisa terdiri dari kelompok, lembaga maupun masyarakat yang tujuannya untuk memberikan gambaran secara mendetail.

\section{Tehnik Pengumpulan Data}

Tehnik pengumpulan data yang digunakan adalah:

a. Studi Kepustakaan yaitu tehnik pengumpulan data dengan melakukan studi tantang data-data yang bersumber atau diperoleh dari bahan bacaan yang ada hubungannya dengan masalah yang ditiliti.

b. Dokumentasi yaitu tehnik pengumpulan data dengan cara mengumpulkan data yang tersedia pada instansi-instansi terkait dengan penelitian ini untuk didokumentasikan, dicacat atau dianalisa sesuai dengan kebutuhan penelitian.

\section{Jenis Data}

Jenis data yang digunakan dalam penelitian ini adalah data kuantatif berupa data sekunder. berupa Data tersebut adalah data PDRBpada setiap sektor sub sektor ekonomi yang membentuk PDRBsetiap Kecamatan dan PDRB Kabupaten Lombok Utara serta data pertumbuhan ekonomi baik pada tingkat kecamatan maupun pada tingkat kabupaten.

\section{Sumber Data}

Data sekunder yang digunakan dalam penelitian ini bersumber dari Kantor BPS NTB dan Kantor Statistik Kabupaten Lombok Utara.

\section{Prosedur Analisis}

Metode Analisis Location Quotion (LQ) Dengan teknik kuantitatif ini, dapat menentukan kapasitas ekspor perekonomian suatu daerah dan derajat kemandirian suatu sektor. Dalam analisis LQ, Kegiatan ekonomi suatu daerah dibagi menjadi dua golongan;

a. Kegiatan sektor yang melayani pasar di daerah itu sendiri maupun diluar daerah yang bersangkutan. Industri seperti ini dinamakan industry basic.

b. Kegiatan sektor yang melayani pasar di daerah tersebut, jenis ini dinamakan industry non basic atau industri lokal.

Teknik membandingkan peranannya dalam perekonomian daerah itu dengan peranan kegiatan sejenis dalam perekonomian regional atau nasional. Adapun formula analisis:

$$
L Q i=\frac{V_{i j} / V_{j}}{V_{i n} / V_{n}}
$$

Dimana:

$\mathrm{V}_{\mathrm{ij}}=$ PDRB sektor $\mathrm{i}$ di Kecamatan $\mathrm{j}$

$\mathrm{V}_{\mathrm{j}}=$ PDRB total Kecamatan $\mathrm{j}$

$\mathrm{V}_{\text {in }}=$ PDRB sektor i Kabupaten Lombok Utara

$\mathrm{V}_{\mathrm{n}}=$ PDRB Total Kabupaten Lombok Utara

Berdasarkan hasil perhitungan Loqation quotient (LQ), dapat diketahui konsentrasi suatu kegiatan pada suatu wilayah dengan kriteria sebagai berikut:

a. Nilai LQ di sektor $i=1$. Ini berarti bahwa sektor tersebut bisa menunjukkan atau berpotensi menjadi sektor basis dan bisa saja berpotensi menjadi sektor non basis

b. Nilai LQ di sektor i> 1. Ini berarti bahwa sektor tersebut termasuk kedalam sektor basis

c. Nilai LQ di sektor $\mathrm{i}<1$. Ini berarti bahwa sektor tersebut tidak termasuk kedalam sektor basis (non basis).

\section{Shift-Share}

Analisis Shift share adalah salah satu teknik kuantitatif yang bisa digunakan untuk menganalisis perubahan struktur ekonomi daerah relatif terhadap struktur ekonomi wilayah administratif yang lebih tinggi sebagai pembanding atau referensi 


\section{Elastisitas - Jurnal Ekonomi Pembangunan \\ Vol. 2 No. 2, September 2020}

informasi dasar yang dapat diperoleh dari analisis Shift-Share, yaitu :

a. Pertumbuhan ekonomi referensi propinsi atau nasional (national growtheffect), yang menunjukkan bagaimana pengaruh pertumbuhan ekonomi nasional atau propinsi terhadap perekonomian daerah.

b. Pergeseran proporsional (proportional shift) yang menunjukkan perubahan relatif kinerja suatu sektor disaerah tertentu terhadap sektor yang sama direferensi propinsi atau nasional.

c. Differensialshift yang memberikan informasi dalam menentukan seberapa jauh daya saing industri daerah (lokal) dengan perekonomian yang Cijadikan referensi

Formula yang digunakan untuk membentuk analisis Shift share adalah sebagai berikut:

1. Dampak riil pertumbuhan ekonomi daerah.

$$
\mathrm{Cij}=\mathrm{N}_{\mathrm{ij}}+\mathrm{M}_{\mathrm{ij}}+\mathrm{C}_{\mathrm{ij}}
$$

2. Pengaruh pertumbuhan ekonomi referensi

$$
N_{i j}=E_{i j} X r_{n}
$$

3. Pergeseran proporsional atau pengaruh bauran industry

$$
\mathrm{M}_{\mathrm{ij}}=\mathrm{E}_{\mathrm{ij}}\left(\mathrm{r}_{\mathrm{in}}-\mathrm{r}_{\mathrm{n}}\right)
$$

4. Pengaruh keunggulan kompetitif

Dimana:

$$
\mathrm{C}_{\mathrm{ij}}=\mathrm{E}_{\mathrm{ij}}\left(\mathrm{r}_{\mathrm{ij}}-\mathrm{r}_{\mathrm{in}}\right)
$$

$E_{i j}=$ Nilai PDRB di sektor $\mathrm{i}$ daerah $\mathrm{j}$

$E_{\text {in }}=$ Nilai PDRB di sektor i nasional

$\mathrm{r}_{\mathrm{ij}}=$ Laju pertumbuhan sektor $\mathrm{i}$ di daerah $\mathrm{j}$

$\mathrm{r}_{\mathrm{n}}=$ Laju pertumbuhan ekonomi nasional

$r_{\text {in }}=$ Laju pertumbuhan sektor i nasional /daerah pembanding

Analisis Klassen Typology

Untuk melihat pola pertumbuhan dan Struktur pertumbuhan berdasarkan sektor ekonomi di setiap kecamatan di Kabupaten Lombok Utara dapat diklasifikasi sebagai berikut:
Tabel 1. Klasifikasi Pertumbuhan Sektor Ekonomi menurut Klassen Typology

\begin{tabular}{|l|l|l|}
\hline $\begin{array}{c}\text { Laju } \\
\text { Pertumbuhan } \\
(\mathbf{r})\end{array}$ & $\begin{array}{l}\text { Kontribusi (P) } \\
\mathbf{P i}>\mathbf{P}\end{array}$ & $\begin{array}{c}\text { Kontribusi (P) } \\
\mathbf{P i}<\mathbf{P}\end{array}$ \\
\hline ri $>\mathrm{r}$ & $\begin{array}{l}\text { Sektor } \\
\text { ekonomi maju } \\
\text { dan cepat } \\
\text { tumbuh }\end{array}$ & $\begin{array}{l}\text { Sektor ekonomi } \\
\text { maju tapi } \\
\text { tertekan }\end{array}$ \\
\hline $\mathrm{ri}<\mathrm{r}$ & $\begin{array}{l}\text { Berkembang } \\
\text { cepat }\end{array}$ & $\begin{array}{l}\text { Relatif } \\
\text { tertinggal }\end{array}$ \\
\hline
\end{tabular}

Keterangan: $\begin{aligned} & \mathrm{Ri}= \text { Rata-rata laju pertumbuhan PDRB } \\ & \text { sektoral pada setiap kecamatan di } \\ & \text { Kabupayen Lombok Utara } \\ & \mathrm{r}= \text { Rata-rata laju pertumbuhan PDRB } \\ & \text { sektoral Kabupaten Lombok Utara. } \\ & \mathrm{Pi}= \text { Rata Kontribusi PDRB sektoral } \\ & \text { pada setiap kecamatan di } \\ & \text { Kabupaten Lombok Utara } \\ & \mathrm{P}= \text { Rata-rata kontribusi PDRB sektoral } \\ & \text { di Kabupaten Lombok Utara. }\end{aligned}$ pontensial dengan cara mencari sektor ekonomi di setiap Kecamatan di Kabupaten Lombok Utara yang memiliki ketiga kereteria yaitu sektor basis, memiliki keunggulan kompetitif (daya saing) serta termasuk keriteria sektor maju dan cepat tumbuh.

\section{Sektor Ekonomi potensial Kecamatan Gangga}

Sektor-sektor ekonomi yang potensial perlu diberikan prioritas untuk pengembangan ekonomi di Kecamatan Gangga adalah sektor basis (LQ>1), sektor yang memiliki keunggulan komparatif (Angka Cij yang positif dan relatif besar), serta sektor ekonomi yang berada pada kuadran I (Kategori I) dan Kuadran ke II (Kategori II) pada Matrix Tipologi Klassen yang dapat di kategorikan sektor potensial. Berdasarkan ketiga keteria tersebut di atas, maka sektor pertanian merupakan sektor ekonomi potensial yang didukung oleh sub sektor peternakan dan hasil-hasilnya serta sub sektor kehutanan. Sektor ekonomi potensial selanjutnya adalah sektor 


\section{Elastisitas - Jurnal Ekonomi Pembangunan \\ Vol. 2 No. 2, September 2020}

penggalian, sub sektor perdagangan, sub sektor sewa bangunan serta sub sektor sosial kemasyarakatan

\section{Sektor Ekonomi Potensial Kecamatan Pemenang}

Sektor-sektor ekonomi yang merupakan sektor basis (LQ > 1), memiliki keunggulan komparatif(Angka $\mathrm{Cij}$ yang relatif besar), serta berada pada kuadran I dan IIpada Tipologi Klasen dapat dikategorikan sebagai sektor ekonomi potensial. Berdasarkan ketiga kriteria yang telah diuraikan sebelunmya, maka di Kecamatan Pemenang,sektor/subsektor yang potensial adalah subsektor perkebunan dan perikanan,air bersih, Bangunan, Hotel \&restoran, Pengangkutan dan Komunikasi, Keuangan \& jasa perusahaan serta sektor Jasa-jasa merupakan sektor-sektor ekonomi yang potensial

\section{Sektor Ekonomi Potensial Kecamatan Tanjung}

Sektor-sektor ekonomi yang merupakan sektor basis (LQ > 1), memiliki keunggulan komparatif(Angka Cij yang relatif besar), serta berada pada kuadran I dan IIpada Tipologi Klasen dapat dikategorikan sebagai sektor ekonomi potensial. Berdasarkan ketiga kriteria yang telah diuraikan sebelunmya, maka di Kecamatan Tanjung,sektor/subsektor yang potensial adalah subsektor perkebunan, penggalian, Industri pengolahan, listrik \& air bersih, Bangunan, Hotel, Pengangkutan dan Komunikasi, Keuangan \& jasa perusahaan serta sektor Jasa-jasa baik jasa pemerintahan umummaupunjasa swasta, merupakan sektor-sektor ekonomi yang potensial

\section{Sektor Ekonomi Potensial Kecamatan Bayan}

Sektor-sektor ekonomi yang merupakan sektor basis ( $\left.\mathrm{LQ}_{\mathrm{i}}>1\right)$, memiliki keunggulan komparatif (Angka Cij positif dan relatif besar), serta berada pada kuadran I, II pada Tipologi Klasen dapat dikatagorikan sebagai sektor ekonomi potensial. Berdasarkan pada ke tiga kriteria tersebut maka Sektor potensial di Kecamatan Bayan adalah Sektor Pertanian, mencakup Sub sektorPerkebunan, Peternakan,Perikanan. Sektor bangunan juga merupakan sektor-sektor ekonomi potensial di Kecamatan Bayan. Sektor lain yangjuga potensial adalah sub sektor tanaman bahan makanan dan sektor

\section{Sektor Ekonomi Potensial Kecamatan Kayangan}

Sektor-sektor ekonomi yang termasuksektor basis $\left(\mathrm{LQ}_{\mathrm{i}}>1\right)$, memiliki keunggulan komparatif (Angka Cijpositif dan relatif besar), serta berada pada kuadran I, II pada Tipologi Klasen, dapat dikatagorikan sebagai sektor ekonomi potensial. Berdasarkan pada ke tiga kriteria tersebut maka Sektor Potensial di Kecamatan Kayangan hanya dua sektor yaitu sektor Pertanian dan sektor Perdagangan, Hotel dan Restoran. Sektor Pertanian adalah Sub Sektor Peternakan. Sektor Perdagangan Hotel dan Restoran.

\section{KESIMPULAN DAN SARAN Kesimpulan}

Sektor dan sub sektor ekonomi yang potensialyang memiliki tiga keriteria pertama adalah sektor dan sub sektor yang memiliki LQ $>1$, kedua sektor maju dan cepat tumbuh serta sektor yang berkembang cepat, ketiga sektor yang mempunyai keunggulan kompetatif . Adapun sektor dan sub sektor ekonomomi potensial yang memenuhi ketiga keriteria tersebut pada :

a. Kecamatan Gangga adalah maka sektor pertanian yang didukung oleh sub sektor peternakan dan hasil-hasilnya serta sub sektor kehutanan. sektor penggalian, sub sektor perdagangan, sub sektor sewa bangunan serta sub sektor sosial kemasyarakatan merupakan sektor dan sub sktor potensial.

b. Pada Kecamatan Pemenang adalah sub sektor perkebunan dan perikanan,air 


\section{Elastisitas - Jurnal Ekonomi Pembangunan \\ Vol. 2 No. 2, September 2020}

bersih, Bangunan, Hotel \&restoran, Pengangkutan dan Komunikasi, Keuangan \& jasa perusahaan serta sektor Jasa-jasa merupakan sektorsektor ekonomi yang potensial.

c. Pada Kecamatan Tanjung,sektor /subsektor yang potensial adalah subsektor perkebunan, penggalian, Industri pengolahan, listrik \& air bersih, Bangunan, Hotel, Pengangkutan dan Komunikasi, Keuangan \& jasa perusahaan serta sektor Jasa-jasa baik jasa pemerintahan umummaupunjasa swasta, merupakan sektor-sektor ekonomi yang potensial

d. PadaKecamatan Bayan adalah Sektor Pertanian, mencakup Sub sektorPerkebunan,

Peternakan,Perikanan. Sektor bangunan juga merupakan sektor-sektor ekonomi potensial di Kecamatan Bayan. Sektor lain yangjuga potensial adalah sub sektor tanaman bahan makanan

e. Pada Kecamatan Kayangan hanya dua sektor yaitu sektor Pertanian dan sektor Perdagangan, Hotel dan Restoran. Sektor Pertanian adalah Sub Sektor Peternakan. Sektor Perdagangan Hotel dan Restoran.

\section{Saran-Saran}

Dari hasil penelitian dan apa yang telah dipaparkan dalam kesimpulan dapat disarankan kepada pemerintah, baik pemerintah Kabupaten Lombok Utaramaupun pemerintah pada setiap kecamatan di sarankan :

a. Dalam pengambilan kebijakankebijakan yang terkait dengan pembangunan, hendaknya mempriroritaskan pembangunan pada sektor-sektor ekonomi yang potensial seperti yang telah dipaparkan dalam kesimpulan.

b. Selain itu, untuk sektor ekonomi yang mandapatkan nilai mendekati satu pada perhitungan basis ekonomi maupun sektor ekonomi yang terletak pada kuadran II pada perhitungan typologi klasen, hendaknya terus diperhatikan sehingga nantinya dapat menjadi sektor yang maju dan tumbuh cepat di kecamatan Tanjung.

c. Kepada pemerintah dan swasta hendaknya mendirikan industri disesuaikan dengan potensi ekonomi masing-masing kecamatan.

\section{REFERENSI}

Adisasmita, R. 2005. Dasar- Dasar Ekonomi Wilayah, Graha ilmu, Yogyakarta

Arsyad, Lincolin, 1999. Pengantar Perencanaan dan Pembangunan Ekonomi Daerah BPFE, Yogyakarta.

Boediono, 1985. Teori Pertumbuhan Ekonomi, BPFE UGM, Yogyakart

Kuncoro, M dan Aswandi, H, 2002. Evaluasi Kawasan Andalan, Studi Emperis di Kalimantan Selatan 1993-1999, Jurnal Ekonomi dan Bisma Indonesia Vol 7 no 1.

Nasir, Mohammad, 1988. Metode Penelitian. Jakarta Ghalia Indonesia.

Radianto, E, 2005. Evaluasi Pembangunan Regional Pasca Kerusuhan Maluku, EKI Vol 51

Sjafrizal, 2008, Ekonomi Regional, Teori dan Aplikasi, Baduose Mediosa, Cetakan Pertama, Padang.

Sukirno, Sadono, 1985, Ekonomi Pembangunan Proses, Masalah dan Dasar Kebijakan LPFE-UI, Jakarta.

Sugiono, 2010, Statistika Untuk Penelitian Alfabet, Bandung.

Tarigan, Robinson, 2004. Ekonomi Regional, Bumi Aksara, Jakarta.

Todaro, Michael P, 1988. Pembangunan Ekonomi Dunia Ketiga, Penerbit Erlangga, Edisi keenam, Jakarta 